Two broad conclusions emerge. In the first place, there are undoubted grounds for an improvement in quality of the cartographical training made available for geographers. Secondly, in view of the probable continued post-war need for specialist cartographers -personnel best recruited from geographers with a good mathematical training - it seems likely that the Government departments will look to the universities of Great Britain when making such professional sppointments. It is therefore not too early to consider an investigation into the probable needs of these departments and the possibility of meeting such needs, not only by the desirable general raising of the standard of cartographical teaching, but also by the creation of advanced courses at selected universities.

\section{A SHORTER HISTORY OF SCIENCE}

\section{A Shorter History of Science}

By Sir William Cecil Dampier. Pp. $\mathrm{x}+190+9$ plates. (Cambridge: At the University Press, 1944.) 7s. 6d. net.

CIR WILLIAM DAMPIER has now published a $\checkmark$ shorter and easier version of his very successful "History of Science". In the preface he says that the readers he has in mind are, first, that rather elusive creature the 'general reader', and, second, those more definable readers who occupy the higher forms of schools. They will either be science students whose science can be broadened, or students of the humanities who need an idea of the place of science in human life. The book should fulfil these requirements very well indeed.

The new volume is less than a third of the length of the earlier one. Thanks to narrow margins, no references in footnotes and thin paper, it can be put into one's pocket. In spite of this, the print is clear and not crowded, and room has been found for nine plates. Six of these are portraits of men of science -Archimedes, Leonardo da Vinci, Galileo, Newton, Darwin and Rutherford. The first portrait is perhaps not very authentic. The last is authentic enough, but is a photograph with that strained expression often seen on passports and not at all characteristic of Rutherford.

The process of compression has been carefully done. By omitting minor lines of investigation and the work of minor contributors, the account has on the whole been made more readable, without any great loss for a book that is not meant to be a work of reference and that supplies a good select bibliography. There is less philosophical discussion but enough to give an outline of that aspect of scientific thought. Parts have been rewritten and some definitely improved, but of course a good deal of the compression has been a matter of scissors and paste. The earlier chapters up to the end of the eighteenth century are highly successful. If the later ones are not quite so good, that is because the immense mass of detail to be considered raises much harder problems. In a few cases compression has gone to the length of obscurity, as in the solitary mention of the work of Langmuir and Adam on surface films (p. 135). The statement about von Baer, the embryologist, at the end of p. 114, has kecome misleading by the omission of statements that explain and qualify it in the larger book. The probability curves shown on pp. 96 and 124 without adequate explanation in the text or under the figure are likely to mystify the innocent reader. This is specially to be regretted, as these curves come into a host of modern problems. Still, these are minor blemishes and there do not seem to be many of them.

For the majority of readers, who are not going to be scientific specialists, but who want a conspectus of the development of seientific thought and practice, the book seems admirably fitted. For those young people who are going to devote themselves to scientific investigation it has one defect, though one it shares with almost anything they are likely to read about the progress of science. That is, that this progress is made to look like an unbroken series of triumphs. Before long these people will discover that the experimental method consists in doing fifty things wrong before doing one right. It might be a help to them (to mention one case only) to hear how it happened that "the incomparable Mr. Newton" himself made one serious mistake and devoted years to chemical experiments which yielded no results. There is no need to go to the other extreme of the cynic who said that "science consists of theories, which nobody believes except the man who first thought of them, and facts, which everybody believes except the man who has last investigated them". Nevertheless, the young do tend to take a rose-coloured view of things, and it is part of the duty of their èlders to disabuse them.

A. D. Ritchie.

\section{BIBLIOTHECA CUSHINGIANA}

The Harvey Cushing Collection of Books and Manuscripts

(Publication No. 1. Historical Library, Yale Medical Library.) Pp. xvi+207. (New York: Schuman's, 1943.) 8.50 dollars.

W TEN Prof. Cushing bequeathed his remarkable library to his old University of Yale, he set aside a fund to be used in cataloguing portions of the collection. The advisory board of the historical library, however, decided to employ this fund in preparing a short-title list of the entire collection. Whether it was advisable to do this, instead of concentrating on a list of only the rarer and more important items, with full collations, was doubtless considered. Cushing's bio-bibliography of Andreas Vesalius, published posthumously, does indeed include such collations of the relevant Vesaliana, and this to some extent favours the decision of the members of the advisory board, who were not in a position to ignore considerations of expense, or to indulge in duplication. Prof. J. F. Fulton, who is devoted to the memory of Cushing, and is himself a learned and experienced bibliographer, favoured the solution adopted, and it will be wise to respect his judgment, although a volume comparable in plan with the Bibliotheca Osleriana would have been most welcome.

The library includes 77 early manuscripts, 168 incunabula, and some 7,500 books, pamphlets and separates. It is therefore not a large collection, but on the other hand it is relatively very rich in the rarest and most desirable works. To assemble such a library, in times when it was possible, postulated the possession of ample means, of knowing what to 